\title{
Godność w prawie pracy
}

W świecie współczesnym coraz więcej mówi się na temat godności człowieka. Podkreśla się, że godność jest wartością absolutną, określa się ją jako wartość wartości ${ }^{1}$. Jej rodowód sięga czasów filozofii starożytnej ${ }^{2}$, ale dopiero po II wojnie światowej jesteśmy świadkami swoistej „rewolucji godności ludzkiej”. Dlatego nie dziwi fakt, że godność jest przedmiotem zainteresowania wielu dziedzin nauki. Temat godności poruszył także Jan Paweł II w encyklice Laborem exercens, poświęconej pracy ludzkiej. Motywem przewodnim encykliki jest praca w wymiarze podmiotowym, czyli człowiek jako podmiot pracy. Papież w tym dokumencie wskazywał na istnienie niebezpieczeństwa uprzedmiotowienia pracownika przez pracodawcę, naruszania jego godności i traktowania go jako narzędzia produkcji. Istotne zatem wydaje się spojrzenie na godność poprzez pryzmat prawa pracy. Należy zastanowić się, jak na gruncie prawa pracy realizuje się myśl Jana Pawła II, że „praca jest dobrem godziwym, czyli odpowiadającym godności człowieka, wyrażającym tę godność i pomnażającym ją"4.

* Malwina KrYszkiewicz, studentka V roku prawa, Wydział Prawa i Administracji, Uniwersytet Kardynała Stefana Wyszyńskiego, 01-938 Warszawa, ul. Wóycickiego 1/3.

1 F. J. MAZUREK, Godność osoby ludzkiej podstawą praw człowieka, Lublin 2001, s. 17-18.

2 Ibidem, s. 23 i $\mathrm{n}$.

3 Temat godności został podjęty w Karcie Narodów Zjednoczonych, Powszechnej Deklaracji Praw Człowieka, we wszystkich innych dokumentach poświęconych prawom człowieka, także w niektórych konstytucjach państwowych (ibidem, s. 11-12). Godność dotycząca sfery stosunków pracy jest uregulowana m.in. w art. 23 Powszechnej Deklaracji Praw Człowieka; w art. 7 lit. 1 pkt II Paktu Praw Gospodarczych, Społecznych i Kulturalnych z dnia 19 grudnia 1966 r., Dz. U. 1977, nr 38, poz. 169; w Europejskiej Kracie Społecznej z dnia 18 października 1961 r., Dz. U. 1999, nr 8, poz. 67.

4 Jan PAWEk II, Laborem exercens, rozdz. 9, [w:] Laborem exercens. Tekst i komentarz, red. J. Chmiel, S. Ryłko, Kraków 1983, s. 9-68. Wszystkie cytaty opatrzone skrótem tytułu (LE) pochodzą z tego wydania. 


\section{Pojęcie godności}

Godność według Jana Pawła II ma dwa ujęcia - filozoficzne i teologiczne. Płaszczyznę filozoficzną stanowią dwa wymiary: ontologiczny (godność wynikająca z duchowego charakteru bytu jako istoty rozumnej i wolnej, będąca wartością niezbywalną) i aksjologiczny (godność - doskonałość, która kształtuje się poprzez działania moralnie wartościowe, dobre) ${ }^{5}$. Jest to godność nabyta ${ }^{6}$. Osoba stanowi byt dynamiczny, ale nie musi zdobywać godności. Godność człowiekowi jest dana i zadana. Norma personalistyczna, przeciwna uprzedmiotowieniu człowieka, sformułowana przez Jana Pawła II, mówi o tym, że osoba nie powinna być środkiem do celu, ponieważ jest ona celem samym w sobie ${ }^{7}$. „Osoba jest takim dobrem, z którym nie godzi się używanie, które nie może być traktowane jako przedmiot użycia i w tej formie jako środek do celu"8. Zatem każdy człowiek, w tym także pracownik, musi być traktowany godnie, nie instrumentalnie ${ }^{9}$.

W ujęciu teologicznym godność wypływa z faktu stworzenia człowieka na obraz i podobieństwo Boże oraz powołania człowieka do panowania w świecie. Ponadto Bóg sam staje się człowiekiem poprzez Wcielenie i zaprasza ludzi do wspólnoty z Nim. Owa wspólnota rozpoczyna się na ziemi. Poprzez sakramenty osoba doskonali swoje życie chrześcijańskie, by osiągnąć życie wieczne ${ }^{10}$. Jak pisze Jan Paweł II, „życie Boże jest bowiem celem, do którego zmierza i jest powołany człowiek żyjący w tym świecie"11. W ten sposób godność ujmuje Papież.

Jednakże godność nie musi być pojmowana tylko w aspekcie filozoficznym czy teologicznym, da się ją również uzasadnić w czysto świecki sposób. Opierając się na podziale zaproponowanym przez A. Dylus możemy mówić o godności wrodzonej i nabytej. Wrodzona to ta, z którą się rodzimy, niezbywalna. Nabytą zdobywamy poprzez pewne działania - to pewne zadanie do spełnienia. Istnieje także godność absolutna i relatywna. Pierwsza z nich, absolutna, czyli stała, należna wyłącznie Bogu i człowiekowi, druga relatywna, czyli stopniowalna, przysługuje

${ }^{5}$ R. CzeKalski, Godność osoby ludzkiej (nauczanie Jana Pawła II), Warszawa 2007, s. 16-17.

${ }^{6}$ Według F. J. Mazurka, godność w pierwszym rozumieniu (ontologiczna, osobowa) jest podstawą praw osoby ludzkiej. Osoba ludzka ma prawo do rozwijania godności w drugim rozumieniu (osobowościowej). Oznacza to, że godność osobowa stanowi cechę przyrodzoną i niezbywalną, natomiast osobowościowa jest poczuciem własnej wartości, czci, honoru, można ją zatem utracić. Por. F. J. MAZUREK, Uniwersalizm i integralność praw osoby ludzkiej, [w:] Prawa człowieka - idea czy rzeczywistość, Warszawa 1998, s. 56, za: R. CzEKALskı, op. cit., s. 16.

7 K. WOJTYŁa, Miłość i odpowiedzialność, Londyn 1964, s. 29-32.

8 Ibidem, s. 30.

${ }^{9} \mathrm{~W}$ ramach społecznej nauki Kościoła dostrzega się przejawy naruszeń godności człowieka m.in. w ekonomicznej koncepcji płacy jako ceny towaru. Według przedstawicieli tej nauki, płacy nie można traktować jako towaru, ponieważ jest ona działaniem osoby ludzkiej. Por. L. Dyczewskı, Słuszna i sprawiedliwa płaca w ujęciu katolickiej nauki społecznej, [w:] Prawo do płacy godziwej, red. K. Rynkiewicz, Warszawa 1994, s. 36-45.

10 R. CzeKalski, op. cit., s. 31-40.

11 Jan PAWEk II, Evangelium vitae, rozdz. 30, Warszawa 1997, s. 56. 
każdej istocie. Wyróżniamy także godność osobową i osobistą. O godności osobowej przesądza sam fakt bycia człowiekiem, zaś godność osobista to pewien szacunek do siebie, dobre imię ${ }^{12}$.

Franciszek Janusz Mazurek rozróżnia godność osobową ${ }^{13}$ i osobowościową. Pierwsza jest godnością niezbywalną i trwałą, druga to doskonałość, osiągana poprzez wychowanie lub pracę nad sobą, niejednakowa dla wszystkich, podlega stopniowaniu. Ponadto możemy mówić o godności osobistej (związanej z poczuciem własnej godności) i społecznej (związanej z pełnionymi funkcjami w społe(zzeństwie $)^{14}$.

Helena Szewczyk wyróżnia godność osobową (ludzką), która przysługuje każdemu człowiekowi bez wyjątku, godność osobistą, traktowaną jako szczególną właściwość jednostki ludzkiej oraz godność występującą łącznie z określoną rolą społeczną, którą dana osoba pełni (np. godność pracownicza) ${ }^{15}$. Wyróżnienie godności pracowniczej ma na celu odejście od traktowania pracownika instrumentalnie (jak to miało miejsce w kapitalizmie wolnokonkurencyjnym) i szanowanie godności jednostki ${ }^{16}$.

Pojęcie godności, zawarte w Kodeksie cywilnym, jest ujmowane w perspektywie dóbr osobistych. Doktryna prawnicza, mówiąc o dobrach osobistych, definiuje je jako uznane przez system prawny wartości, obejmujące fizyczną i psychiczną integralność człowieka, jego indywidualność oraz godność i pozycję w społeczeństwie, co stanowi przesłankę samorealizacji osoby ludzkiej" ${ }^{17}$. Godność nie znajduje się w katalogu dóbr wymienionych $w$ art. 23 k.c., jednakże jest połączona - zdaniem większości autorów - z czcią ujmowaną w aspekcie wewnętrznym ${ }^{18}$.

Powstaje zatem wątpliwość, jak należy rozumieć godność na gruncie prawa pracy. Pojęcie godności zostało wprowadzone do Kodeksu pracy ustawą nowelizującą z dnia 2 lutego 1996 r. ${ }^{19}$ jako jedno z dóbr osobistych, które pracodawca zobowiązany jest szanować (art. $11^{1}$ k.p.). Wcześniej, w okresie międzywojennym i do wejścia w życie Kodeksu pracy, obowiązywał art. 449 Kodeksu zobowiązań

12 A. Dylus wskazuje, że problem poszanowania godności w prawie pracy dotyczy godności nabytej, relatywnej, osobistej. Godność absolutna pozostaje nienaruszalna w każdych warunkach. Por. A. DyLus, Godność człowieka w procesie pracy, [w:] Godność pracownika kategorią prawa pracy, Warszawa 2001, s. 14-19.

13 F. J. Mazurek wskazuje, że określając wrodzoną i niezbywalną godność doktryna posługuje się następującymi pojęciami: godność człowieka, godność osoby, godność osobowa, godność osoby ludzkiej, godność bytu ludzkiego. Por. F. J. MAZUREK, Godność osoby..., s. 19.

14 Ibidem, s. 19-20.

15 H. SzEwczYk, Ochrona dóbr osobistych w zatrudnieniu, Warszawa 2007, s. 27.

16 Por. ibidem, s. 36-40.

17 Z. Radwański, Prawo cywilne - część ogólna, Warszawa 2009, s. 156.

18 I. Boruta zauważa, że większość zwolenników doktryny utożsamia godność z czcią wewnętrzną, jednak godność obejmuje także dobre imię; zob. I. BORUTA, Godność człowieka - kategorią prawa pracy, [w:] Konferencja naukowa: Godność pracownika - kategorią prawa pracy, Warszawa 2001, s. 34-35.

19 Ustawa z dnia 2 lutego 1996 o zmianie ustawy - Kodeks pracy oraz zmianie niektórych ustaw, Dz. U. 1996, nr 24, poz. 110. 
z 1933 r. stanowiący, że pracodawca powinien przyzwoicie obchodzić się z pracownikami i szanować ich godność osobistą ${ }^{20}$. W związku z tym przepisem Kodeksu zobowiązań cześć doktryny wydzieliła z godności ludzkiej pojęcie godności pracowniczej, definiując je jako „[...] poczucie własnej wartości, oparte na opinii dobrego fachowca i sumiennego pracownika w bliskim pracownikowi środowisku oraz na uznaniu wkładu, zdolności, umiejętności i pracy przez bliższych i dalszych przełożonych, a więc to, co tworzy pracowniczą godność [...]"21. Teoria ta została poddana krytyce. Według Teresy Liszcz, „pojęcie godności pracownika w kontekście art. $11^{1}$ k.p. jest tożsame z pojęciem godności osobistej pracownika, tyle że odniesionym do człowieka pełniącego społeczną rolę pracownika"22. Irena Boruta stwierdza, że godność powinna być rozumiana jako zakaz instrumentalnego traktowania pracownika przez pracodawcę ${ }^{23}$.

\section{Godność jako podstawowa zasada prawa pracy i jej ochrona}

Artykuł $11^{1}$ k.p. stanowi, że „pracodawca jest obowiązany szanować godność i inne dobra osobiste pracownika". Zasada ta ma charakter postulatywny i normatywny. Postulatywność wyraża się w zakazie instrumentalnego traktowania pracownika przez osobę zatrudniającą, ale także przez organa stanowiące i stosujące prawo. $Z$ normatywności wynika natomiast obowiązek poszanowania przez pracodawcę godności oraz innych dóbr osobistych pracownika ${ }^{24}$. Intencją ustawodawcy wprowadzającego art. $11^{1}$ k.p. była ochrona przed przedmiotowym traktowaniem pracowników w stosunkach pracy ${ }^{25}$.

Ustawodawca zalicza poszanowanie godności pracownika do podstawowych zasad prawa pracy, jednak nie precyzuje tego obowiązku pracodawcy, nie przewiduje wprost sankcji za jej naruszenie, brakuje też innych odniesień do dóbr osobistych w Kodeksie pracy ${ }^{26}$. Poszanowanie oznacza zakaz ingerencji pracodawcy i osób trzecich w sferę godności. W przypadku jej naruszenia pracownik może skorzystać z rozwiązań zawartych $w$ art. $55 \S 1^{1}$ k.p. Ponadto ma prawo domagać się ochrony godności na podstawie art. 23 i 24 k.c. Istotne zatem wydaje się wyjaśnienie relacji między art. $11^{1}$ k.p. a art. 23 i 24 k.c. Zaproponowane zostały dwa ujęcia.

${ }^{20}$ Rozporządzenie Prezydenta Rzeczypospolitej z dnia 27 października 1933 r., Kodeks zobowiązań, Dz. U. 1933, nr 82, poz. 598.

21 J. JońCZYk, Spory ze stosunku pracy, Warszawa 1965, s. 135.

22 T. Liszcz, Prawo pracy, Warszawa 2011, s. 81.

23 I. BORUTA, op. cit., s. 36.

24 D. DörRe-Nowak, Ochrona godności i innych dóbr osobistych pracownika, Warszawa 2005, S. 34-35.

25 Uzasadnienie projektu ustawy z dnia 2 lutego $1996 \mathrm{r}$. o zmianie ustawy - Kodeks pracy oraz o zmianie niektórych ustaw, Dz. U. 1996, nr 24, poz. 110.

26 D. DÖrRE-NowaK, op. cit., s. 35. 
Pierwsze ujęcie mówi o tym, że ochrona dóbr pracownika została uregulowana w art. $11^{1}$ k.p., a w zakresie nieuregulowanym stosowałoby się odpowiednio przepisy art. 23 i 24 k.c. na podstawie art. 300 k.p. ${ }^{27}$ Drugie przyjmuje, że ochrona dóbr osobistych pracownika jest regulowana na podstawie art. 23 i 24 k.c. oraz art. $11^{1}$ k.p. (pomija się art. 300 k.p.) ${ }^{28}$. Zatem prawodawca pozwolił na zbieg przepisów dotyczących ochrony dóbr osobistych ${ }^{29}$. Pierwsze ujęcie prowadzi do stwierdzenia, że ochrona przez pracodawcę dóbr osobistych jest elementem treści stosunku pracy z uwagi na treść art. $11^{1}$ k.p. i jego umieszczenie w Kodeksie pracy ${ }^{30}$. Drugie, iż zakres ochrony pracownika wyznaczają kumulatywnie przepisy art. $11^{1}$ k.p. oraz art. 23 i 24 k.c. W piśmiennictwie prezentowane są różne poglądy, część autorów opowiada się za pierwszą relacją Kodeksu pracy do Kodeksu cywilnego (m.in. T. Romer, D. Dörre-Nowak), inni za słuszną uważają drugą koncepcję (m.in. I. Boruta, H. Szewczyk ${ }^{31}$.

Brak wprost wyrażonej w Kodeksie pracy sankcji za naruszenie godności i dóbr osobistych pracownika ${ }^{32}$ nie oznacza, że pracownikowi nie przysługuje w związku z naruszeniem godności i innych dóbr osobistych żadne roszczenie. Otóż, jak wspomniałam wyżej, może on dochodzić ochrony swoich praw na gruncie art. 23 i 24 k.c. W prawie cywilnym są to roszczenia majątkowe i niemajątkowe. Niemajątkowe, czyli roszczenia o ustalenie, o zaniechanie działań zagrażających lub naruszających godność pracowniczą, o dokonanie czynności potrzebnych do usunięcia skutków naruszenia. Roszczenia majątkowe to roszczenia o zadośćuczynienie pieniężne za doznaną krzywdę lub o zasądzenie odpowiedniej sumy pieniężnej na cel społeczny, wskazany przez osobę, której dobro zostało naruszone oraz roszczenie o naprawienie szkody. Na podstawie Kodeksu pracy w przypadku rażącego naruszenia przez pracodawcę obowiązku wyrażonego w art. $11^{1}$ k.p. pracownik może rozwiązać umowę o pracę na podstawie art. 55 $\S 1^{1}$ k.p. ${ }^{33}$ z zachowaniem prawa do odszkodowania w wysokości wynagrodzenia

${ }^{27}$ Art. 300 k.p.: „W sprawach nie unormowanych przepisami prawa pracy do stosunku pracy stosuje się odpowiednio przepisy Kodeksu cywilnego, jeżeli nie są one sprzeczne z zasadami prawa pracy".

28 I. BORUTA, op. cit., s. 39.

29 H. SZEWCZYK, op. cit., s. 149.

30 Ibidem, s. 147.

31 Ibidem, s. 145-151.

32 Do wyjątków można zaliczyć art. $18^{3 \mathrm{~d}}$ k.p. mówiący o naruszeniu przez pracodawcę zasady równego traktowania, skutkującym możliwością domagania się odszkodowania w wysokości nie niższej niż minimalne wynagrodzenie za pracę oraz art. $94^{3} \S 3$ i 4 k.p. przewidujący prawo domagania się od pracodawcy zadośćuczynienia pieniężnego za doznaną krzywdę w przypadku mobbingu, który wywołał rozstrój zdrowia, a gdy pracownik w wyniku mobbingu rozwiązał umowę o pracę ma prawo dochodzić odszkodowania nie niższego niż minimalne wynagrodzenie ze pracę. Zdarzenia naruszenia zasady równego traktowania czy przeciwdziałanie mobbingowi mogą w pewnych przypadkach stanowić naruszenie dóbr osobistych pracownika, o których mówi art. $11^{1}$ k.p. Por. D. DöRRE-NOWAK, op. cit., s. 63.

33 Art. 55 § 1 k.p. stanowi, że pracownik może rozwiązać umowę o pracę bez wypowiedzenia, jeżeli zostanie wydane orzeczenie lekarskie stwierdzające szkodliwy wpływ wykonywanej pracy na zdrowie pracownika, a pracodawca nie przeniesie go w terminie wskazanym w orzeczeniu 
za okres wypowiedzenia, a jeżeli umowa o pracę została zawarta na czas określony lub na czas wykonywania określonej pracy - w wysokości wynagrodzenia za 2 tygodnie.

\section{Ochrona godności według Laborem exercens}

Jan Paweł II dostrzega zagrożenia godności ludzkiej na obszarze prawa pracy, stąd też w „wielkiej moralnej konstytucji pracy”, jak określa encyklikę Teresa Liszcz $^{34}$, podejmuje analizę podstawowych uprawnień, które przysługują człowiekowi jako pracownikowi. Wśród nich warto wymienić m.in. prawo do zatrudnienia, prawo do sprawiedliwej zapłaty, uprawnienie do zrzeszania się. Papież nie wspomina o obowiązkach pracownika, być może z racji tego, że problemem jest nadużywanie silniejszej pozycji przez pracodawców, skutkujące właśnie naruszaniem godności pracowniczej ${ }^{35}$. Wskazuje, że praca stanowi podstawowy wymiar bytowania człowieka na ziemi (LE 4), dlatego tak ważne jest zapewnienie każdemu możliwości podjęcia zarobkowania. Mówiąc o pracy, zwraca uwagę na jej aspekt przedmiotowy. Jednakże podkreśla, iż praca nie może sprowadzać się tylko do techniki i samych produktów. Jej podmiotem zawsze jest człowiek. Poprzez pracę osoba urzeczywistnia siebie i kształtuje w sobie poczucie wartości. Wszystkie czynności wykonywane przez człowieka mają służyć urzeczywistnianiu jego człowieczeństwa (LE 6). Zatem praca nie tylko jest dobrem użytecznym, lecz także godziwym ${ }^{36}$.

\footnotetext{
lekarskim do innej pracy, odpowiedniej ze względu na stan jego zdrowia i kwalifikacje zawodowe. Według $\S 1^{1}$ tego przepisu k.p. pracownik może rozwiązać umowę o pracę $w$ trybie określonym w $\S 1$ także wtedy, gdy pracodawca dopuścił się ciężkiego naruszenia podstawowych obowiązków wobec pracownika; w tym przypadku pracownikowi przysługuje odszkodowanie w wysokości wynagrodzenia za okres wypowiedzenia, a jeżeli umowa o pracę została zawarta na czas określony lub na czas wykonywania określonej pracy - w wysokości wynagrodzenia za okres 2 tygodni.

34 T. Lıszcz, Papież Jan Paweł II o pracy - w 25 rocznice ogłoszenia encykliki „Laborem exercens”, „Praca i Zabezpieczenie Społeczne” 2006, nr 10, s. 7.

35 Ibidem.

${ }^{36}$ Por. F. Longchamps de Bérier, Jan Paweł Il o prawie do pracy $i$ zabezpieczenia społecznego. W pierwszą rocznicę śmierci, „Praca i Zabezpieczenie Społeczne” 2006, nr 4, s. 2-6.
} 